\title{
Microfacies, Depositional Model and Reservoir Characterization of Upper Cretaceous Kawagarh Formation, Qamar Mela Section, Nizampur Basin, Khyber Pakhtunkhwa, Pakistan
}

\author{
Salman Ahmad Khattak ${ }^{1}$, Samiullah ${ }^{2}$, Muhammad Salman ${ }^{2}$ \\ ${ }^{1}$ MS Department of Geology, University of Peshawar, Peshawar \\ ${ }^{2}$ BS Department of Earth Sciences, University of Haripur, Haripur
}

\section{INFORMASI NASKAH}

Diterima: 22 Juni 2021

Direvisi: 19 November 2021

Disetujui: 19 November 2021

Terbit: 19 November 2021

Email korespondensi:

salman@uoh.edu.pk

Laman daring:

https://doi.org/10.37525/

$\mathrm{mz} / 2021-2 / 286$

\begin{abstract}
The present study main focused on reservoir Characterization of the Upper Cretaceous Kawagarh Formation from Qamar Mela Section, Nizampur Basin. The samples were collected from the field by using standard procedures involving section measurement, lithological logging and photography. The collected samples were used to prepare the thin sections followed by petrographic analysis using Optika microscope in the laboratory. To explore the reservoir potential, we studied the impact of diagenesis on reservoir potential, supplemented by plug porosity and permeability, and SEM analysis. The outcrop is mainly composed of limestone and marl. Fifteen samples were studied from $45 \mathrm{~m}$ thick section and two main microfacies were identified. The microfacies includes; (1). Mudstone microfacies (planktonic foraminiferal mudstone and dolomitic mudstone submicrofacies), (2). Radiolarian bioclastic planktonic foraminiferal wackestone microfacies. The environment of deposition interpreted on the basis of microfacies for Kawagarh Formation is inner ramp to outer ramp and deep basinal settings. The Kawagarh Formation is also modified by various diagenetic features including compaction, dolomitization, dissolution, pyrite precipitation, cementation and spar filled fractures representing meteoric to marine phreatic with mixing zone and burial diagenetic environments. Dissolution, fracturing and dolomitization are the diagenetic processes which enhanced the porosity while cementation, pyrite precipitation and compaction decreased the porosity. Plug porosity and permeability offour rock samples averages $1.69 \%$ and $0.267 \mathrm{Ka} / \mathrm{md}$, respectively. SEM analysis shows different types of porosity includes vuggy, shelter and intergranular. The low porosity and permeability levels of Kawagarh Formation suggest only a modest reservoir potential.
\end{abstract}

Keywords: Kawagarh Formation, Reservoir Characterization, Impact, plug porosity and permeability 


\section{INTRODUCTION}

The name Kawagarh Formation was formalized by the Stratigraphic Committee of Pakistan Fatmi (1973) for the Kawagarh Shale of Cotter (1933) from its type locality in the Kawagarh Hills in northern Kala Chitta Range and extended for similar exposures in the Hazara Mountains, the Samana Range and the Kohat Plateau. As such the Kawagarh Formation is extensively exposed in the Kala Chitta Range, Hazara Basin, Nizampur and Kohat areas (Kadri, 1995; Shah, 2009). The Kawagarh Formation has been studied in detail by Fatmi (1977) from its type locality and adjoining areas of Nizampur, western and eastern Kohat (Mazari Tang and Wuch Khwar sections) and northern Kala Chitta Range. The Kawagarh Formation has disconformable contacts with both the underlying Lumshiwal Formation of Early Cretaceous age and the overlying Hangu Formation of Paleocene age (Shah, 2009).

Rapid northward movement of India from near Madagascar in the Late Cretaceous, triggered major global transgression resulting in the deposition of Kawagarh Formation in northern Kala Chitta Range, Hazara and Kohat (Ahsan et al., 1993a, 1994; Munir et al., 2005; Ahsan, 2008). Absence of Kawagarh Formation from the southern Kala Chitta Range, Salt Range and some parts of Trans Indus ranges is attributed to the reason that these areas were not submerged by the Late Cretaceous transgression (Ahsan et al., 2015). This transgressive cycle ended in Campanian before Maastrichtian (Bard et al., 1979). The initial contact of the Indian Plate with the Kohistan Island Arc (KIA) at $67 \pm 2$ Ma prior to the main India-Eurasia collision at 50-55
Ma resulted in a widespread regression which exposed the upper Maastrichtian strata of Kawagarh Formation (Bard et al., 1979). It resulted in uplifting the shelf and lateritization of the Kawagarh Formation (Chaudhry et al., 1994).

The sedimentalogical and biostratigraphical aspects of the Kawagarh Formation have been studied in detail in Hazara Basin (Latif, 1962; Wadia, 1975; Chaudhry et al., 1992; Ahsan, 1993; Ahsan et al., 1993a, 1993b, 1994; Ahsan and Chaudhry, 1998; Ahsan et al., 2001; Munir et al., 2005; Sameeni et al., 2007; Ahsan, 2008; Shah, 2009; Khan et al., 2010). The sedimentology and biostratigraphy of the Kawagarh Formation in northern Kala Chitta Range were studied for the first time by Qureshi et al. (2004). According to them, the Kawagarh Formation is riddled with planktonic foraminifera and also contains some palynomorphs. Campanian age to the Kawagarh Formation was assigned by Masood et al. (2008) on the basis of the palynological studies in Kala Chitta Range where they found Ptrospermella australliensis. The Kala Chitta Range is a part of the foreland-fold and thrust belt lies to the north of the hydrocarbon bearing Potwar sub-basin and to the south of Attock Cherat Range and Plio-Pliestocene Peshawar Basin. The Kala Chitta Range is in alignment with Hazara Mountains on the east which merge into the Margalla Hills while towards west Samana Range and Kohat are present (Qureshi et al., 2004; Masood et al., 2008).

The surprising hydrocarbon discoveries in Potwar and Kohat sub-basins enhanced the confidence level of explorationists. With this approach the Peshawar-Hazara basins and Kala 
Chitta-Margalla Hills ranges are considered to have good prospectivity (Iqbal et al., 2007). The correlation of Kawagarh Formation in Upper Indus Basin can be made with the Late Cretaceous succession i.e. Pab Sandstone, Mughal Kot Formation and Parh Limestone of the Axial Belt and the Sulaiman and Kirthar provinces in the Lower Indus Basin which has been potentially rich in hydrocarbons (Shah, 2009). Despite being economically important for having reservoir potential, the Kawagarh Formation has attained less attention in the past. Owing to a general paucity of the relevant published literature, the proposed study is being undertaken to carry out the sedimentology and reservoir characterization of Kawagarh Formation from the Nizampur Basin.

\section{Location and Accessibility}

Geographically, the Qamar Mela Section is located in the Nizampur valley of District Nowshera, Khyber Pakhtunkhwa. The Qamar Mela Section is located to the north of Indus River and south of Attock-Cherat Ranges. The outcrop is accessible by metalled road from Khairabad to Nizampur through Qamar Mela Village.

\section{METHODOLOGY}

During the field, general stratigraphy of the study area was observed but the main focus remained on the collecting samples for petrographic analysis, Plug porosity and Permeability and SEM Analysis of Kawagarh Formation. The instruments used in the field were; measuring tape, geological hammer, hand lens, $10 \%$ dilute HCL and G.P.S. Fifteen thin sections were prepared in the rock cutting laboratory of Department of Geology, University of Peshawar. The prepared thin sections were studied under polarizing microscope in the petrographic lab of Department of Geology, University of Haripur.

The photomicrographs of the thin sections were taken in the Sedimentology Laboratory of National Centre of Excellence in Geology, University of Peshawar. Plug porosity and permeability of the representative rock samples were determined in the laboratory of Hydrocarbon Development Institute of Pakistan. Porosity tests of four samples were performed at 500 psi (overburden pressure) and permeability tests of four samples were performed at 400 psi (overburden pressure). SEM analysis was done in the Centralize Resource Laboratory, Department of Physics, University of Peshawar.

SEM analysis is a high-magnification technique used for characterization of conventional rock type. It utilizes secondary and backscattered electron imaging to produce high resolution photomicrographs. SEM analysis identifies rock's mineral morphology, characterizes pore geometry and flow path (Brains, 2015). 


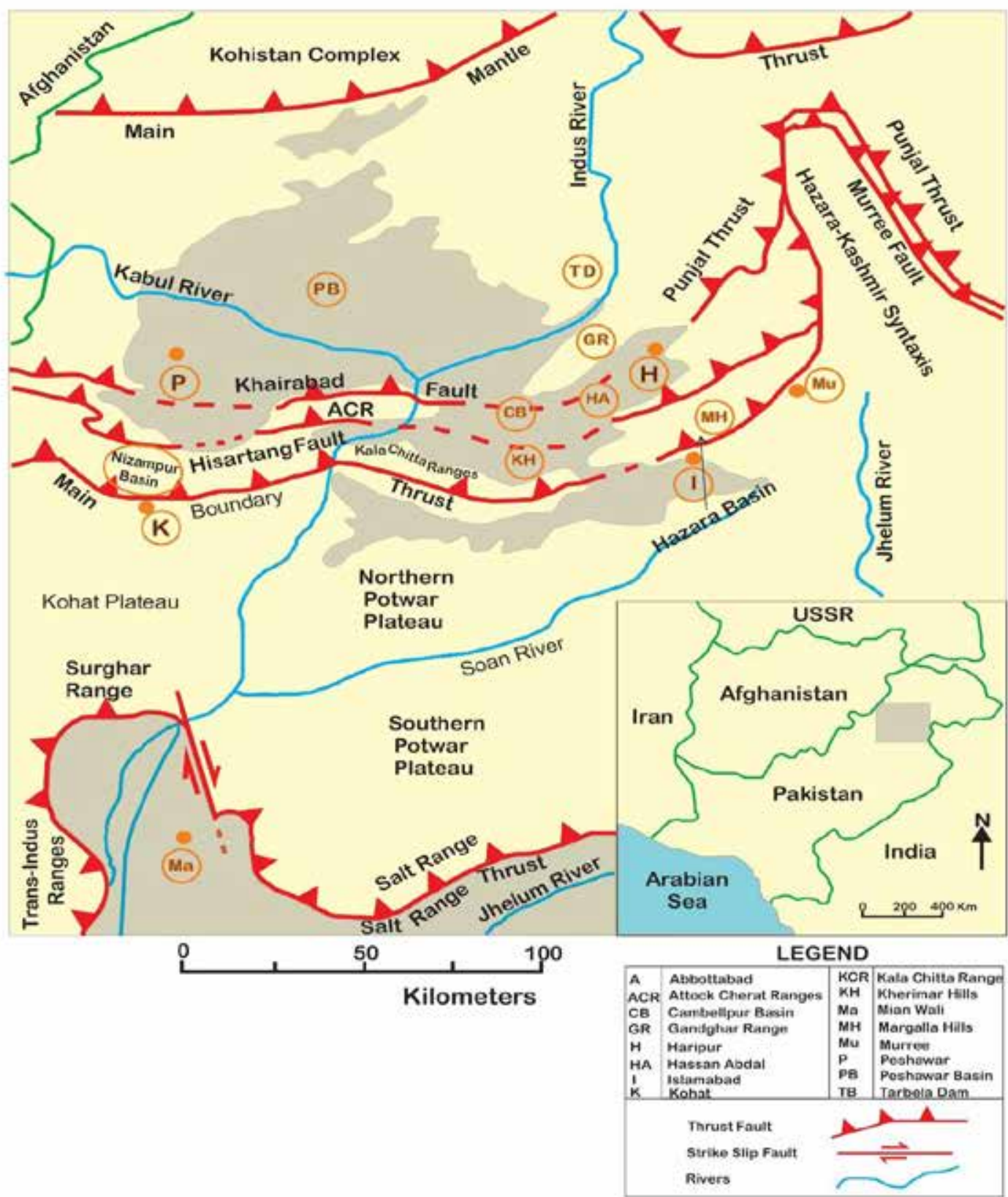

Fig 1. A tectonic map of northern Pakistan, showing major structure boundaries modified after Holland et al,

\section{RESULTS}

Kawagarh Formation at the Qamar Mela Section is located at 33046'20.7"N and $71^{\circ} 53^{\prime} 08.7^{\prime \prime E}$. Systematic sampling was done from the $45 \mathrm{~m}$ thick section with the help of measuring tape and collected 15 samples at an interval of $3 \mathrm{~m}$ from the Kawagarh Formation. The Kawagarh Formation comprised of limestone and marl. The bedding of Kawagarh Formation varied in thickness i.e. very thin bedded, thin and thin to medium bedded and thick bedded (Plate $2.1 \& 2.2$ ). The color of fresh surface of rocks was light grey, dark grey and creamish whereas the weathered surface color was light brown and brownish grey. Small fractures and veins were also 
present. The lower contact of Kawagarh Formation was conformable with Lumshiwal Formation of Early Cretaceous age which comprises maroon color sandstone while the upper contact was conformable with Lockhart Formation of Paleocene age which consist of dark gray, semi-nodular limestone (Fig 3 and Fig 4).

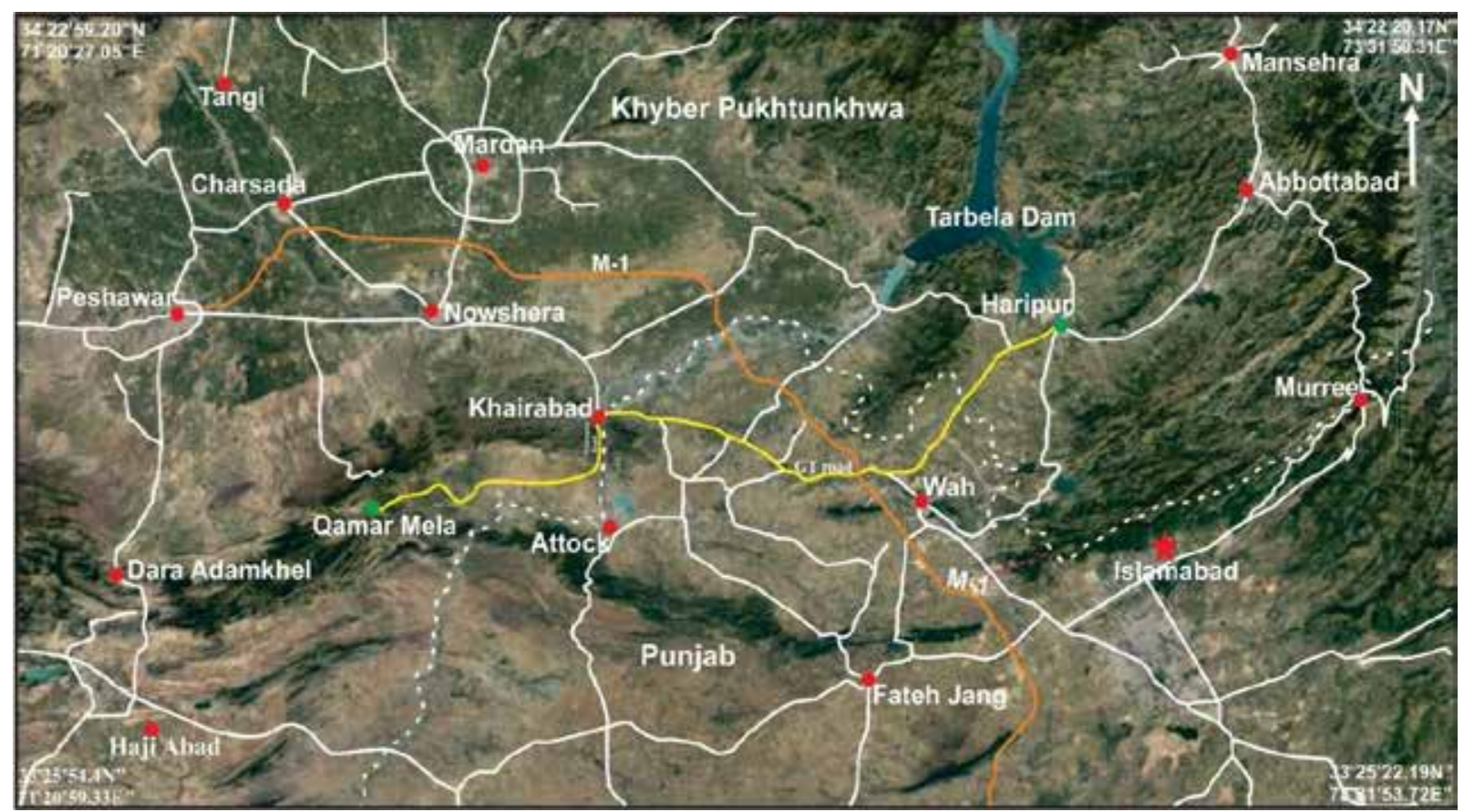

Fig 2. A map generated from Google earth showing the accessibility of the Qamar Mela Section. The Yellow line showing the accessibility road to the study area, white lines showing the GT road and its link roads while orange line (M-1) showing Islamabad-Peshawar Motorway. Red color circles showing major cities.

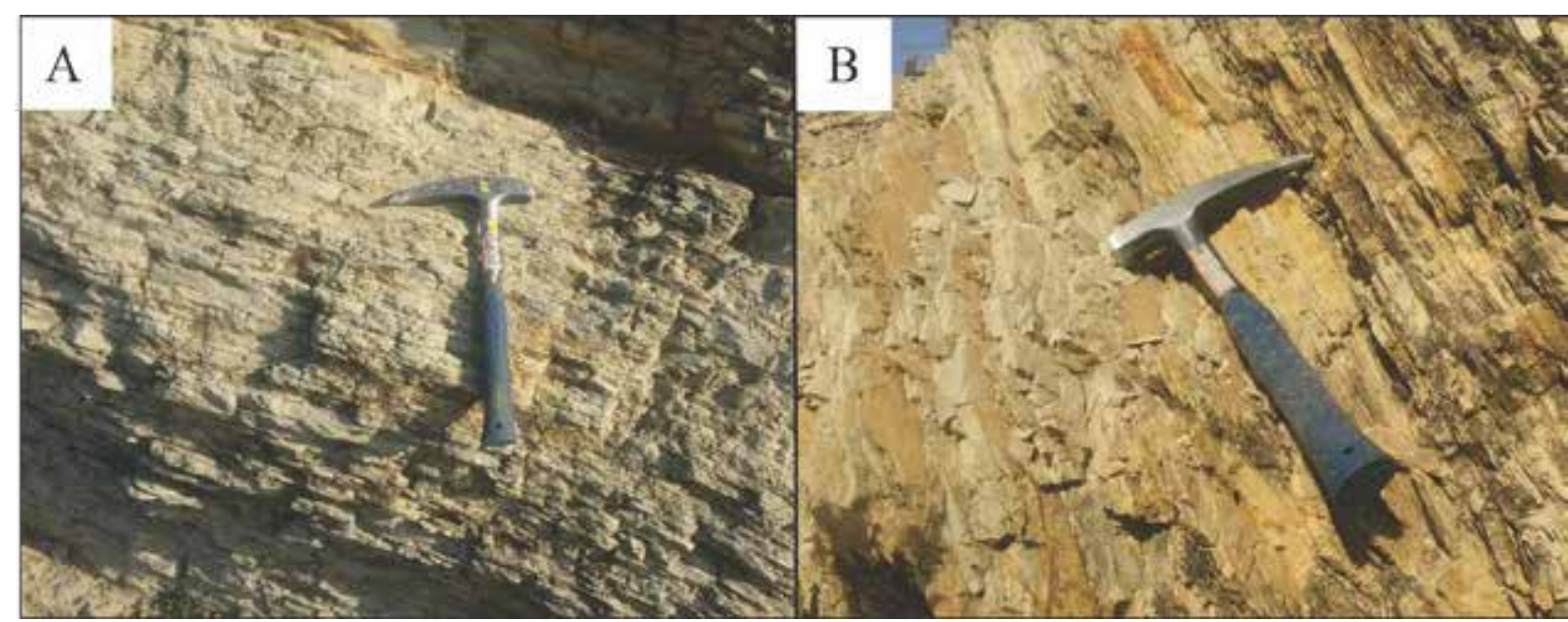

Fig 3. (A) Showing thickly bedded limestone. (B) Showing weathered creamish color marl Kawagarh Formation in Qamar Mela Section (geological hammer length $=32 \mathrm{~cm}$ for scale).

\section{A. Microfacies}

In order to calculate the percentage of allochem constituents, visual method has been applied. About 30-35 views of each thin section were taken. From these views an average allochem constituents and grain to 
matrix ratio has been worked out. In this case, if the grains to matrix ratio is $3: 7$ this means that $30 \%$ allochems and $70 \%$ lime mud. The same procedure has been adopted for the facies with grains to matrix ratio. The mudstone microfacies is divided in to sub-microfacies.

The microfacies are given below:

1. Planktonic foraminifera mudstone sub-

\section{microfacies}

2. Dolomitic mudstone sub-microfacies.

3. Radiolarian bioclastic foraminifera wackestone microfacies.

The key petrographic features noted are type and percentage of carbonate grains (allochems), amount of carbonate matrix (micrite) and spar (cement) (Fig 5).

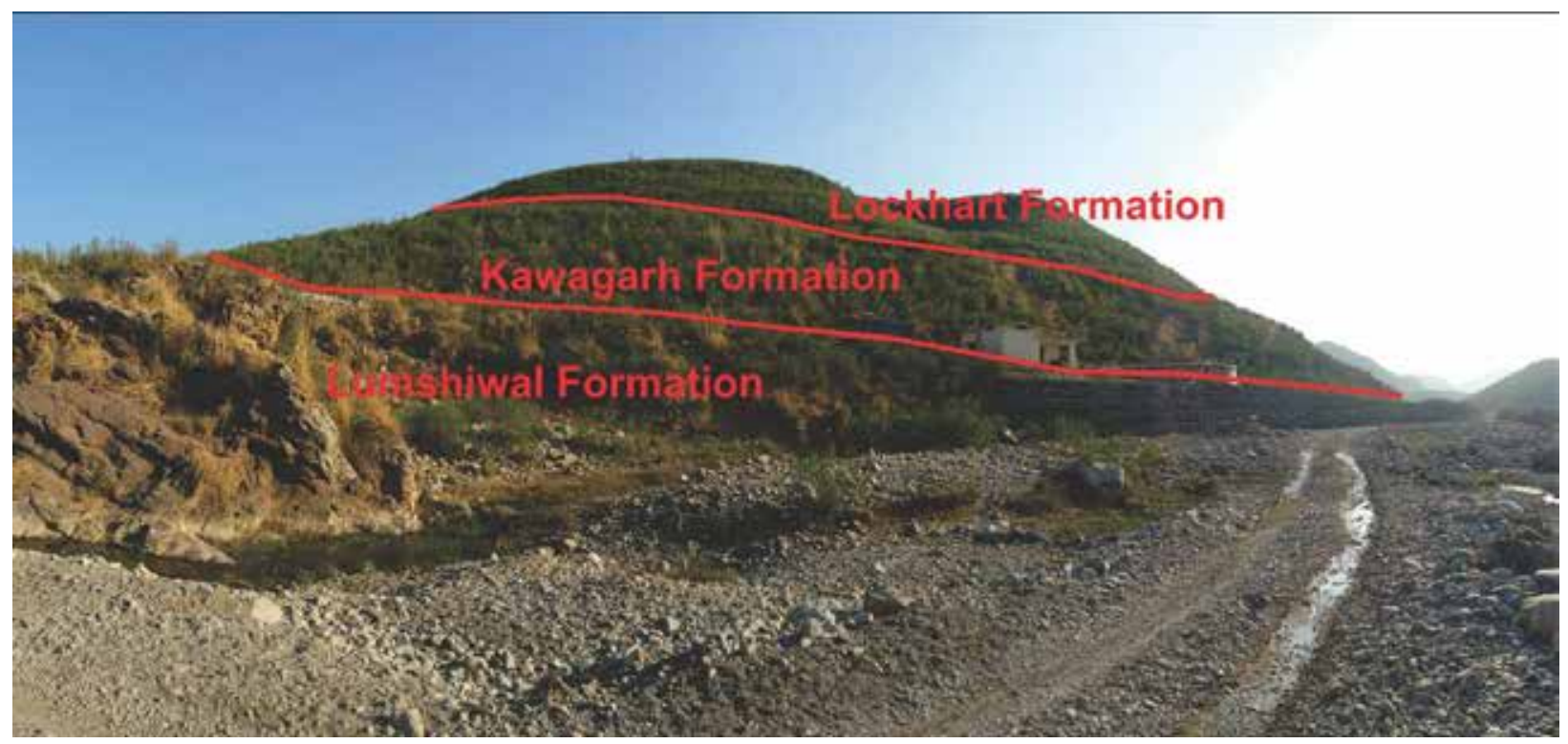

Fig 4. Showing lower contact of Kawagarh formation with Lumshiwal formation and Upper contact with Lochart Formation

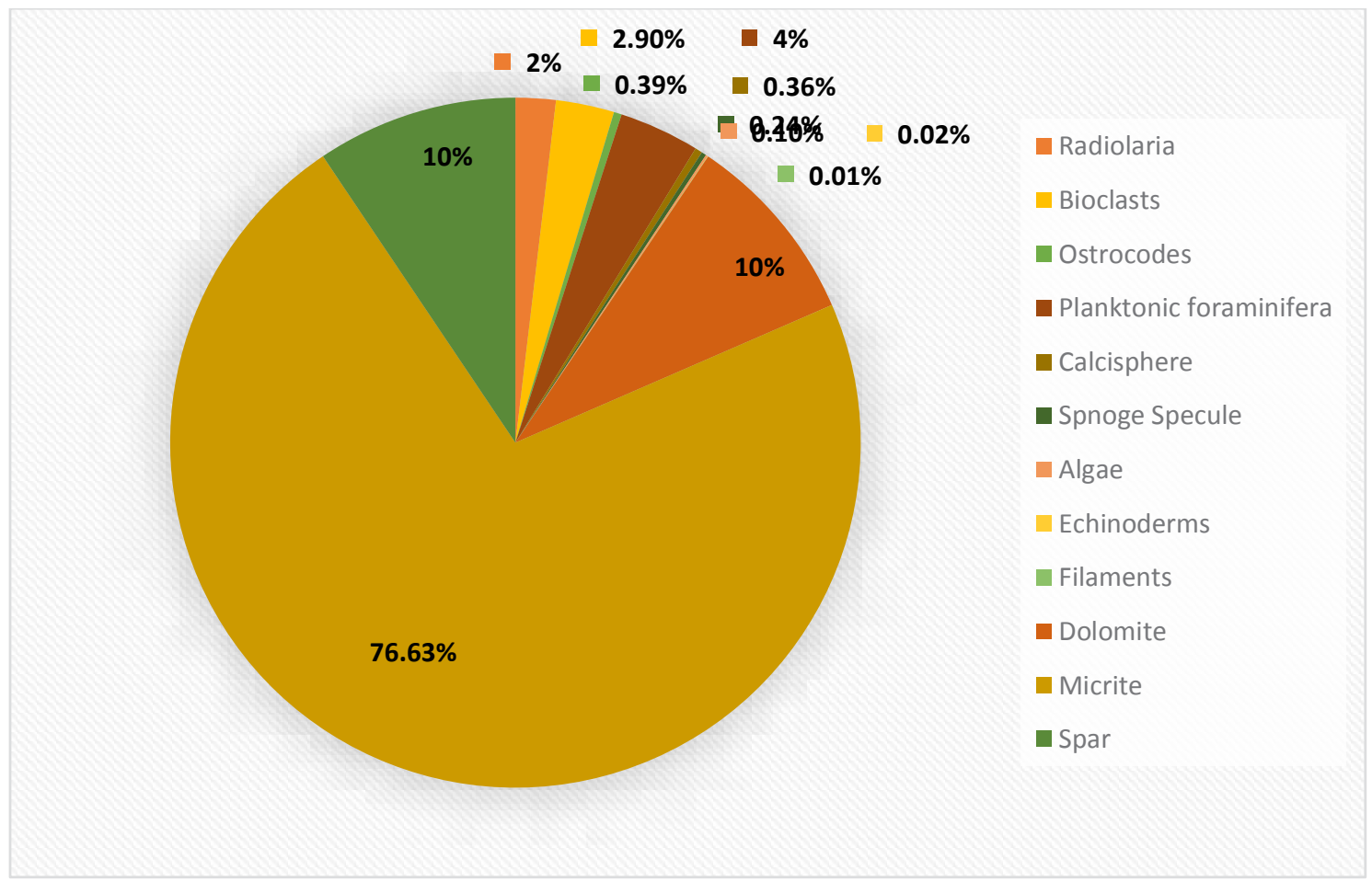

Fig 5. Showing the 'pie chart of percentage of allochems present in Kawagarh Formation in the study area. 
The detailed petrographic description and interpretation of the microfacies of the Kawagarh Formation are given below:

\section{Mudstone Microfacies}

\section{Planktonic Foraminifera Mudstone Sub- Microfacies}

Description

The main constituents of this submicrofacies is mud and minor amount of allochems are present. The average value of mud is $96 \%$ while $4 \%$ allochems are present. The allochems present are planktonic foraminifera, ostracods, bioclasts, calcisphere, and sponge. The dominant allochems is planktonic foraminifera $(2 \%)$. Bioclasts are the broken fragments of the fossils (Fig 6, Fig 7).

Interpretation

The submicrofacies are lime mud dominated and have scarce grains. Mud is common in deeper outer ramps and in protected areas of inner ramps Flügel (2004). The lime mud supported nature with scarcity of skeletal grains and presence of planktons and sponge spicules suggests that the facies was deposited in calm, deeper water of outer ramps. The microfacies can be attributed to SMF3 of Wilson (1975) and Flügel (2004), Standard Facies zone (FZ1B) of modified Wilson model (Flügel 2004).

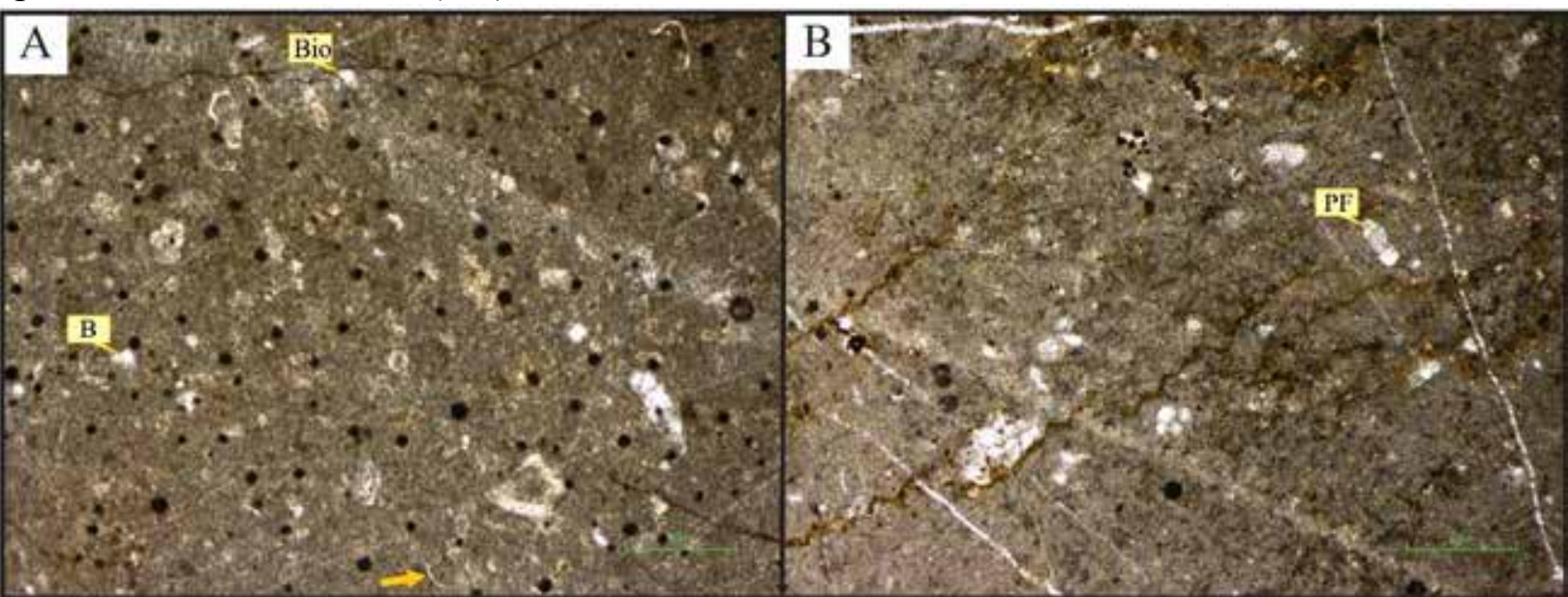

Fig 6. Photomicrographs showing planktonic foraminifera mudstone sub-microfacies. (A) Showing bioclasts (Bio) and ostracods (yellow arrow). (B) Showing planktonic foraminifera (PF).

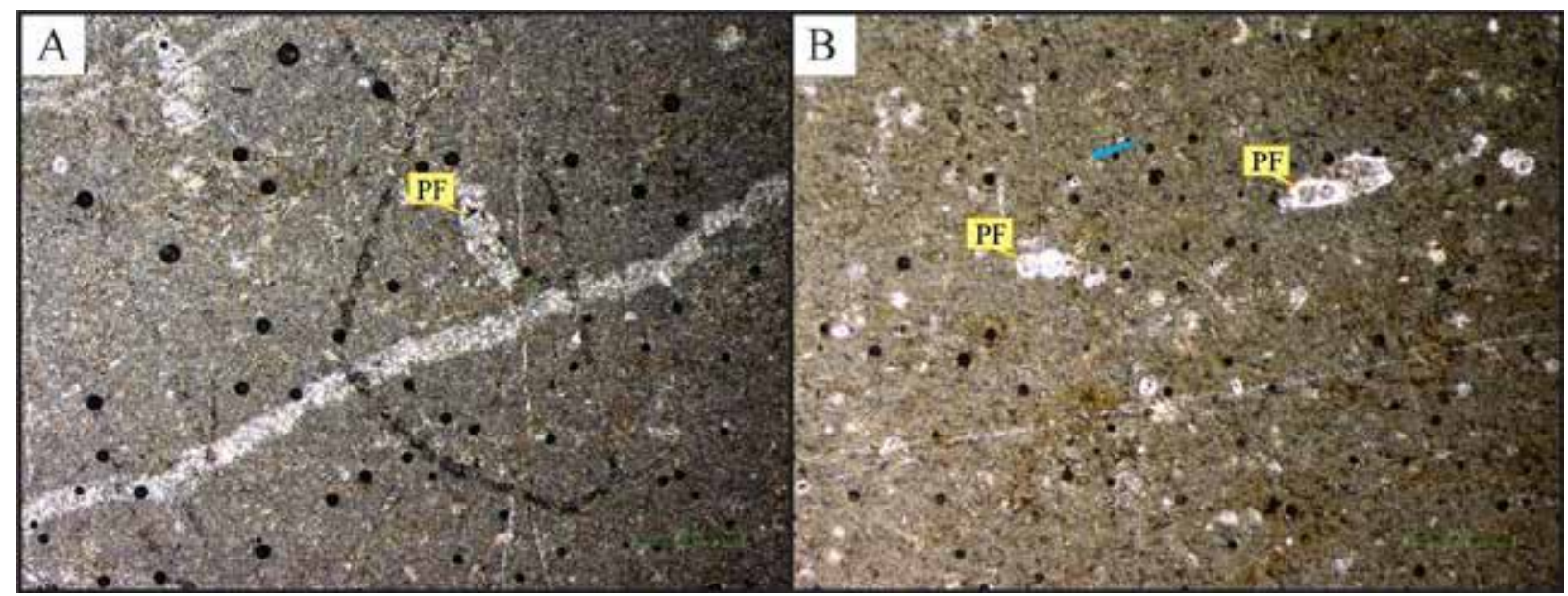

Fig 7. Photomicrographs showing planktonic foraminifera mudstone sub-microfacies (A) Showing planktonic foraminifera (PF). (B) Showing sponge spicule (blue arrow) and planktonic foraminifera (PF). 


\section{Dolomitic Mudstone Sub-Microfacies} Description

The submicrofacies contain dolomitic grains and rare amount of allochems. This submicrofacies is dominantly consisting of $25 \%$ matrix and $75 \%$ allochems of these rock units, which is represented mainly by dolomite $(72 \%)$ with scare amount of planktonic foraminifera, calcisphere and bioclasts (Fig 8, Fig 9).

Interpretation

This submicrofacies consists of dolomitic mudstone. The dolomitization is secondary which is produced by flow of solution enriched in iron and magnesium. Well-developed rhomb of dolomite are present and dolomitization is selective in nature (Plate 3.2). This facies is attributed to SMF3 and 23 of Wilson (1975) and Flügel (2004). Unfossiliferous lime mudstone or fine grained dolomicrite, sometimes with authigenic evaporate minerals, deposited in saline and evaporative environment. The environment of deposition is inner ramp to middle ramp Wilson (1975) and Flügel (2004).

\section{Radiolarian Bioclastic Planktonic Foraminifera Wackestone Microfacies}

Description

This facies has allochemical constituents to matrix ratio of $1.45: 8.53$. Among these allochemical constituents dominant constituents are planktonic foraminifera $(6 \%)$ followed by radiolarians (4\%) and bioclasts $(5 \%)$. In this microfacies ostracods, sponge spicules and calcispheres occur as minor constituents (Fig 10, Fig 11).

Interpretation

The lime mud supported fabric suggests a calm environment for the facies. The presence of planktons along with bioclasts and radiolarian suggest that these facies were deposited in the outer ramp basinal settings (Flügel, 2004). In outer ramp there is little evidences of direct storm reworking exists, but various storm related deposits may occur. The facies correlate with the outer ramp facies of the carbonate ramp models (Burchette and Wright, 1992) with low energy carbonates with hemi pelagic sedimentation. The facies is attributed to Standard Microfacies (SMF 1) type of Wilson (1975) and Flügel (2004) with pelagic lime mudstone and wackestone with planktonic microfossils.

\section{B. Depositional Model}

In carbonate rocks, substantial amount of skeletal grains along with sedimentary structures is generally used for the

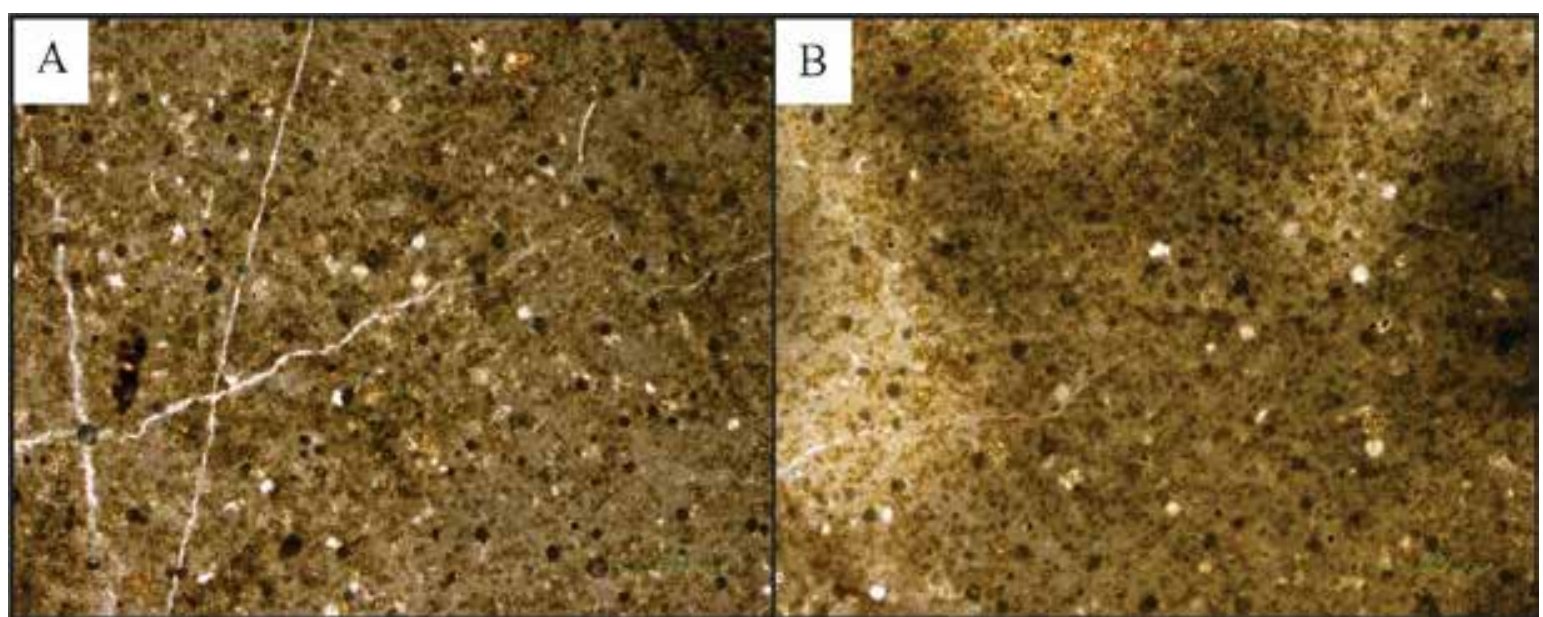

Fig 8. Photomicrographs showing dolomitic mudstone sub-microfacies. (A) and (B) showing adhesive dolomitization 


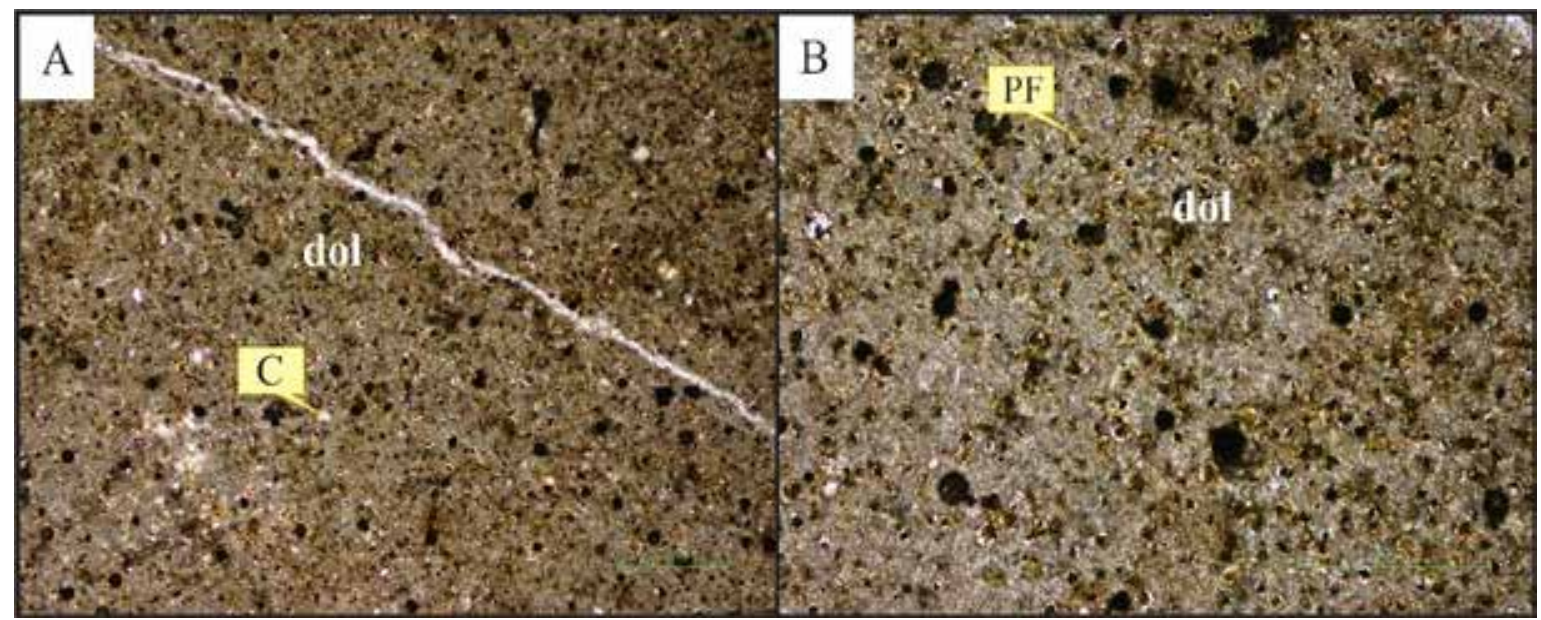

Fig 9. Photomicrographs showing dolomitic mudstone sub-microfacies (A) Showing dolomite (dol) and calcisphere (C). (B) Showing planktonic foraminifera (PF) and dolomitization (dol).

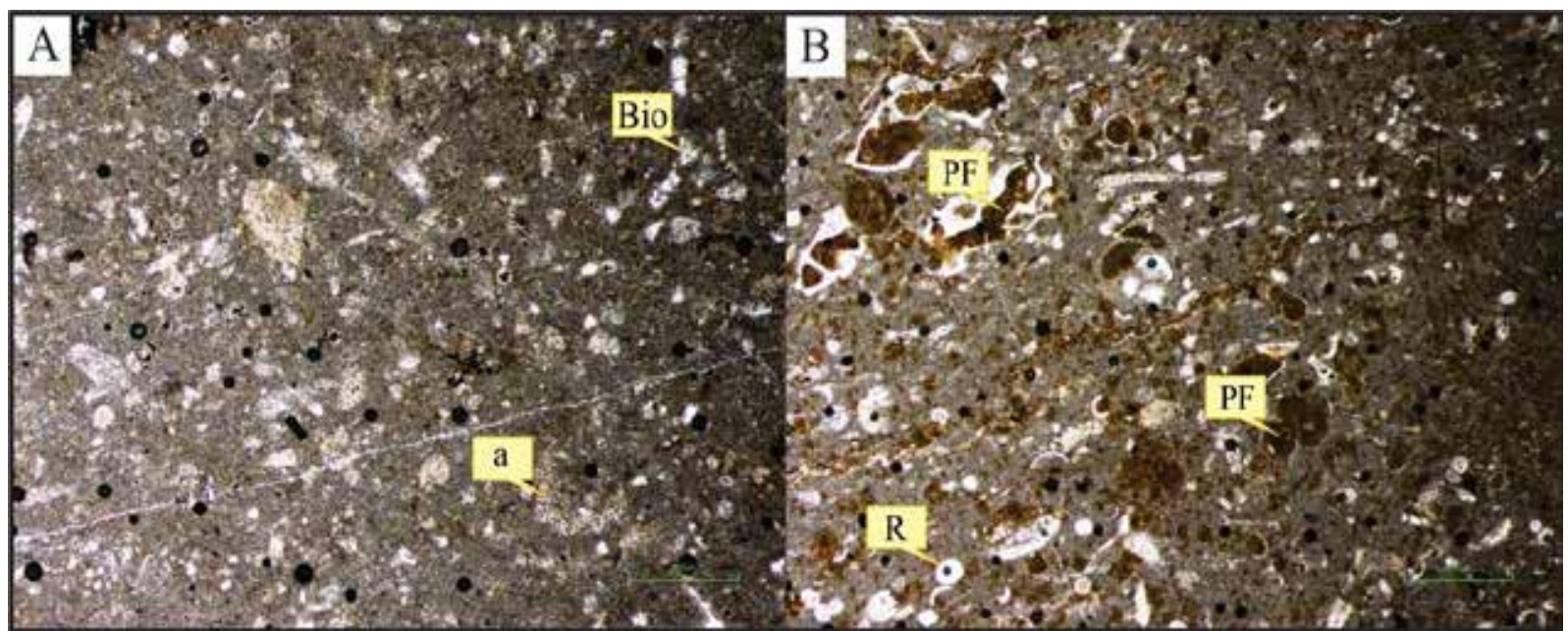

Fig 10. Photomicrographs showing radiolarian bioclastic planktonic foraminifera wackestone sub-microfacies. (A) Showing bioclasts (Bio) and algae (a). (B) Showing planktonic foraminifera (PF) and radiolarian (R).

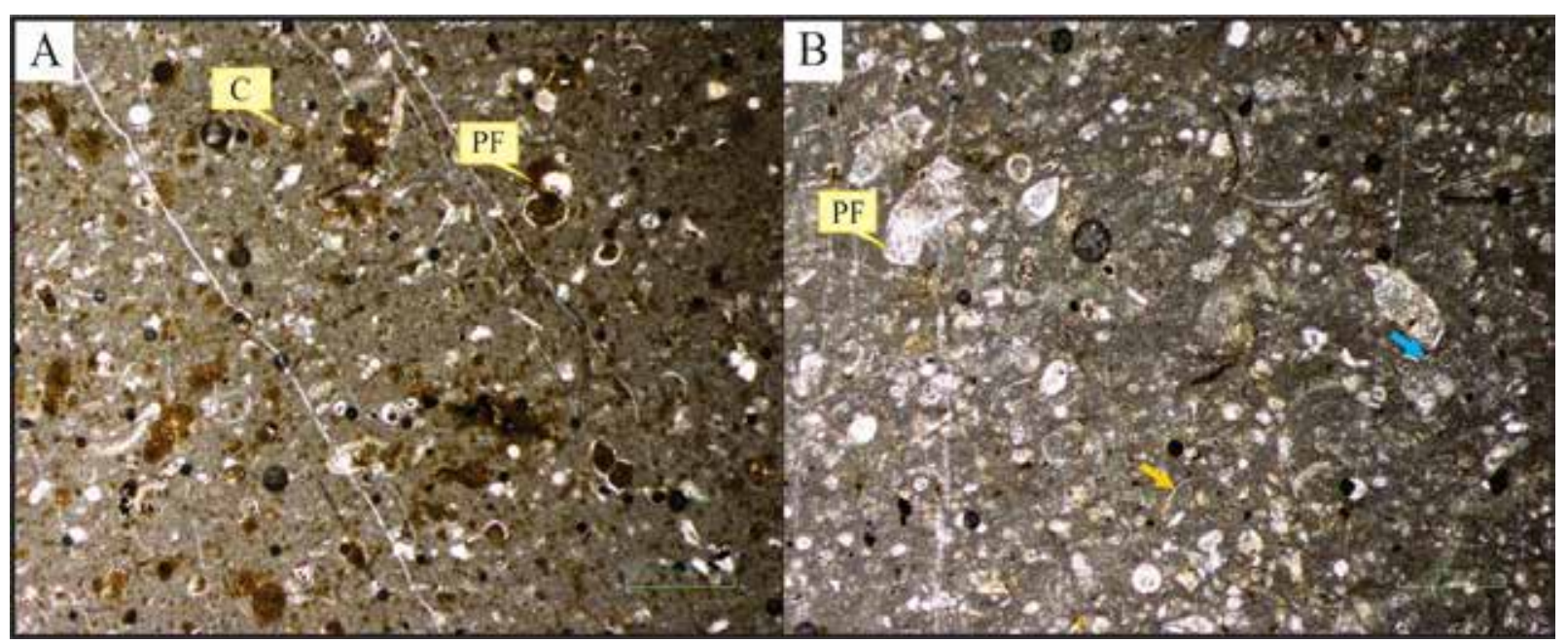

Fig 11. Photomicrographs showing radiolarian bioclastic planktonic foraminifera wackestone (A) Showing planktonic foraminifera (PF) and calcisphere (C). (B) Showing ostracods (yellow arrow), sponge (blue arrow) and planktonic foraminifera $(\mathrm{PF})$. 
Section is shown in Plate 3.8. The depositional environment are constructed on the basis of available petrographic detail. The microfacies of Kawagarh Formation consists of planktonic foraminifera, radiolarian, calcispheres, sponge spicules, mollusks, algae, echinoderms, filaments, bioclasts and abundance of lime mud. The main diagnostic feature of these facies are planktonic foraminifera, radiolarian and abundance of mud. Planktonic foraminifera are the significant skeletal constituent of Upper Cretaceous marine carbonates and represent a variety of depositional environment (Frank, 2010). The high ratio of planktons are the indicators of deep water conditions like outer ramp and middle and outer shelf (Butt, 1986; Nichlos, 2009). Limestone and cherts with abundant radiolarians are generally thought to represent deep-marine deposits (Flügel, 2004). The manifestation of shallow water invasion (Inner Ramp) is evident from the dolomitic mudstone facies. The above brief discussion interprets a ramp type platform setting for deposition of Kawagarh Formation in Qamar Mela Section, Nizampur Basin, Khyber Pakhtunkhwa, Pakistan. (Fig 12).

\section{Reservoir Characterization of Kawagarh Formation}

Major diagenetic processes that effect Kawagarh Formation in Qamar Mela Section include: Compaction, Dissolution, Cementation, Pyrite precipitation, Dolomitization, Fractures. (Fig 12, Fig 13) The reservoir characterization of Kawagarh Formation has been investigated using the following parameters:

1. Impact of diagenesis on reservoir Potential.

2. Plug porosity \& permeability

3. SEM analysis

\section{Impact of Diagenesis On Reservoir Potential}

Porosity and permeability are the important geologic factors that control reservoir quality in oil and gas reservoirs. Diagenetic processes significantly affect porosity and permeability, which control the final geometry of the pore space, orientation and packing of grains, and the degree of cementation and clay filling of pore spaces (Wilson, 1994; Primmer et al., 1997; Molenaar, 1998; Jeans, 2000; Burley and Worden, 2003; Gao et al., 2009). The Kawagarh Formation undergoes various diagenetic processes that effect the reservoir properties of the formation. Those processes which reduced the reservoir potential includes compaction and cementation. Compaction started immediately after deposition. Stylolites is the type of compaction, which formed during burial or tectonic stresses of mudstone and wackestone decrease the porosity and permeability of the formation. Cementation is an important diagenetic process which reduce the porosity.

The degree of cementation varies from thin cement coatings around the grains that partially fill the pores and alter permeability patterns to calcite spar that completely fill the pores. Those diagenetic processes enhanced the reservoir potential includes dissolution, dolomitization and fracturing. Dissolution creates and enhance porosity. Fractures that formed due to uplifting, enhance the secondary porosity. Dissolution enlarges fractures and interparticle dolomite cement grows on the dolomite crystal faces, reducing reservoir quality. It also enhance the porosity because dolomite are denser and occupy less volume than original calcite (Bathurst, 1971). 


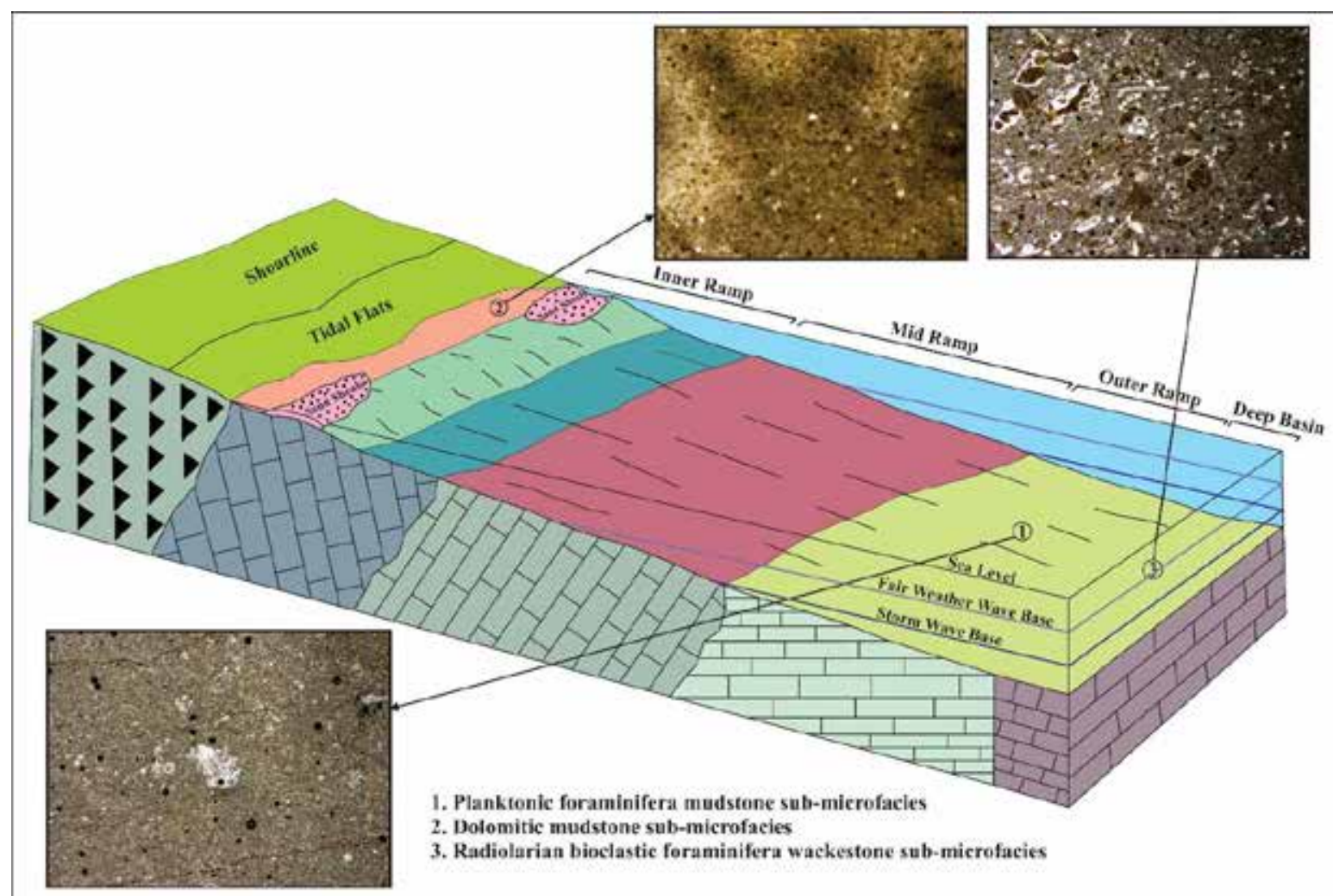

Fig 12. Depositional model of Kawagarh Formation, Qamar Mela Section, Nizampur Basin.

\section{Plug Porosity And Permeability}

Porosity in the carbonate rocks result from many processes, during deposition and after deposition. Porosity is the percentage of the bulk volume of a rock that is occupied by interstices, whether isolated or connected. Primary porosity form during the predepositional stage and depositional stage whereas. Secondary porosity is formed by diagenesis at any time after deposition i.e. by fracturing, dissolution, dolomitization. Porosity may develop as a result of burrowing and boring organisms. Permeability is the measure of ability of rock to allow fluids to pass through it. In the present study plug porosity and permeability of Kawagarh Formation is determined in the Reservoir Engineering Lab of Hydrocarbon Development Institute of Pakistan. Porosity tests of four samples were performed at 500 psi (overburden pressure) and permeability tests of same samples performed at 400 psi (overburden pressure). The following result were obtained as shown in table 5.1. Overall the plug porosity and permeability values are very low i.e. porosity $1.69 \%$ and permeability $0.267 \mathrm{Ka} / \mathrm{md}$ (Fig $15)$. 


\section{Artikel}

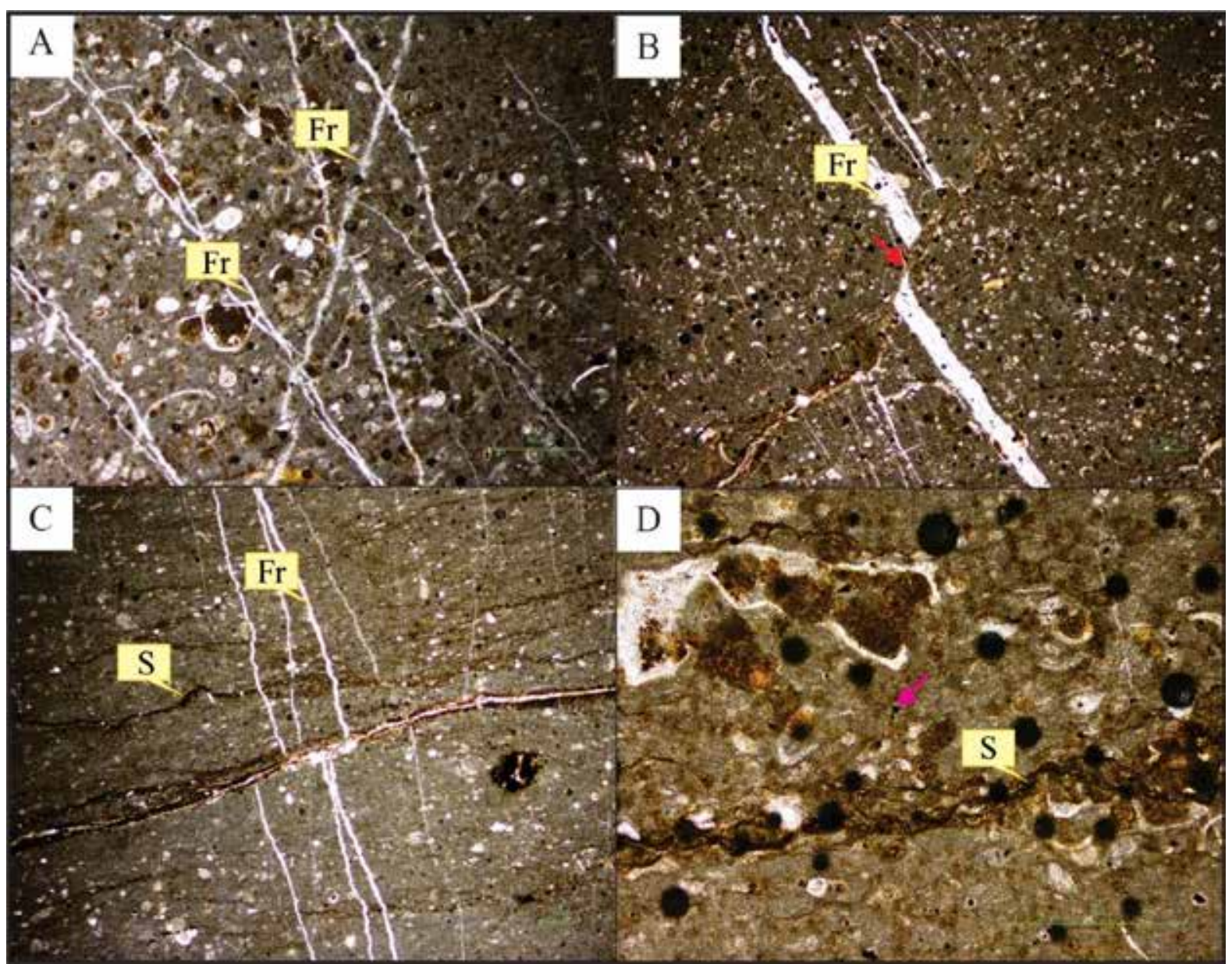

Fig 13. Photomicrographs showing fracture and pyrite precipitation. (A) Showing multiple phase of fractures (Fr).

(B) A view of cross cutting between stylolite (red arrow) and fracture (Fr). (C) Showing fractures (Fr) and stylolite (S). (D) Showing stylolite (S) that mark second phase of pyrite precipitation and 1st phase of pyrite precipitation (pink arrow).

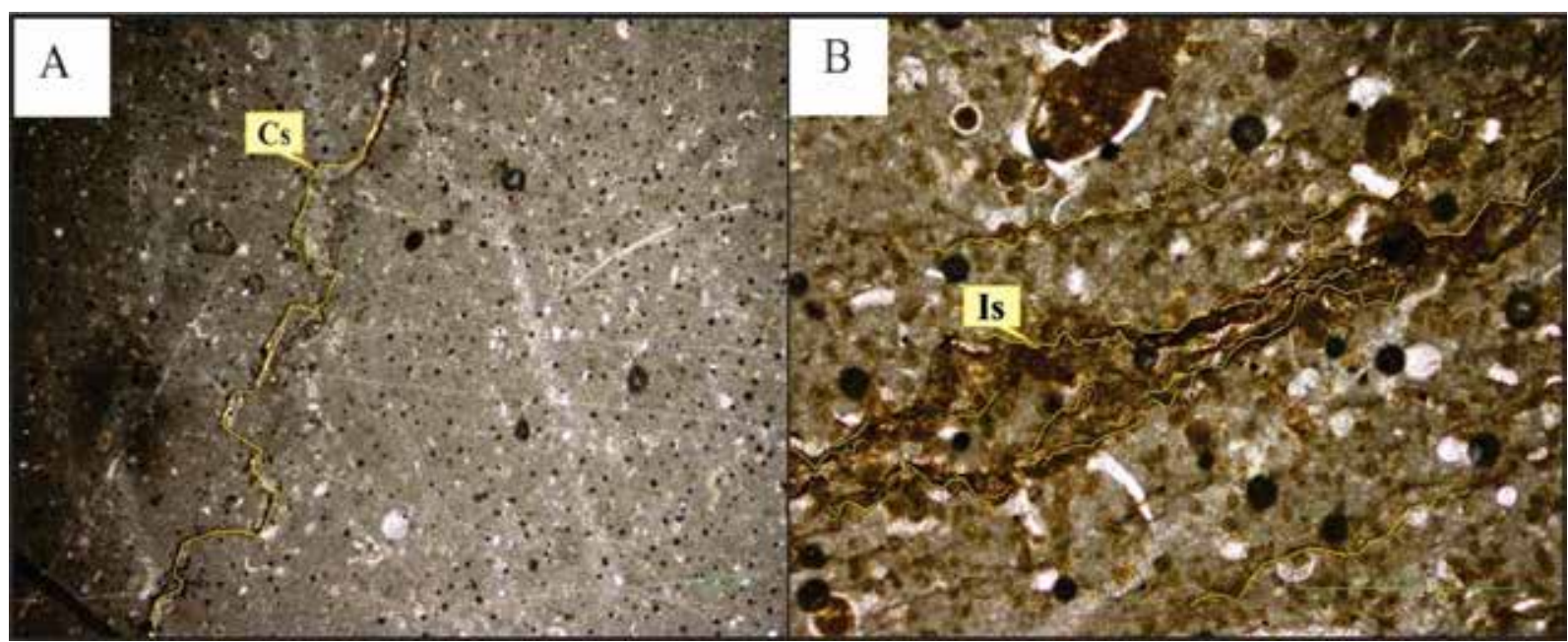

Fig 14. Photomicrographs showing compaction. (A) Showing columnar stylolites (Cs). (B) Showing high amplitude, irregular anastomosing set of stylolites (Is). 


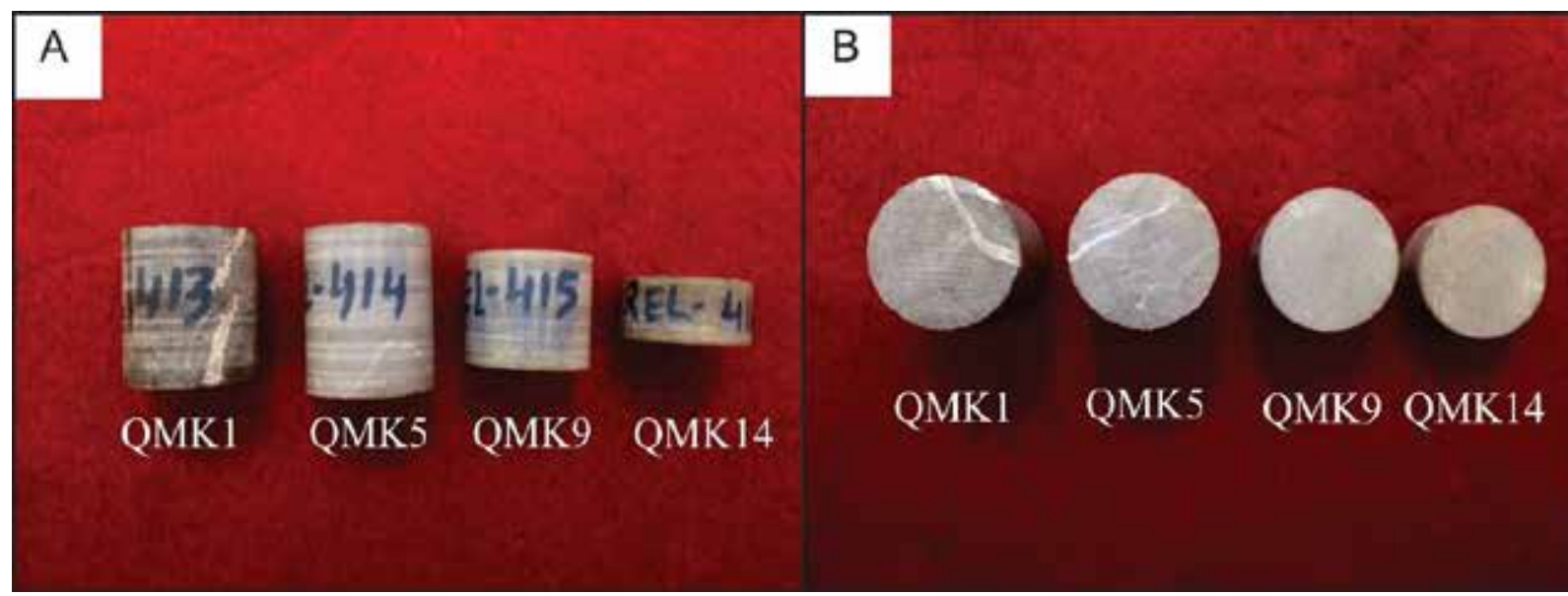

Fig 15. Pictures of plugs for plug porosity and permeability test. (A) Side view of plugs. (B) Top view of plugs.

Table 1. Results of the samples analyzed for porosity and permeability of Kawagarh Formation, Qamar Mela Section, Nizampur Basin.

\begin{tabular}{cccc}
\hline S. No. & Sample \# & Porosity \% & Permeability Ka/md \\
\hline 1 & QKM 1 & 1.95 & 1.050 \\
2 & OKM 5 & 0.71 & 0.000 \\
3 & QKM 9 & 1.41 & 0.000 \\
4 & OKM 14 & 2.71 & 0.020 \\
\hline
\end{tabular}

\section{SEM Analysis}

SEM analysis is a high-magnification technique used for characterization of conventional rock type. It utilizes secondary and backscattered electron imaging to produce high resolution photomicrographs. SEM analysis identifies rock's mineral morphology, characterizes pore geometry and flow path (Brains, 2015). The SEM analysis of Kawagarh Formation indicated vuggy porosity, shelter porosity, quartz, acicular cementation and micro pores (Fig 16,17,18). Vuggy porosity is formed by dissolution of grains and shelter porosity which is formed by shelter and umbrella effect of the large grains which prevent the infilling of pore space underneath lying and therefore enhance the porosity. Quartz was deposited in the vugs and grains and therefore decreased the porosity. Microspores determined in the formation was formed by partial dissolution of grains, which enhance the porosity. 


\section{Artikel}

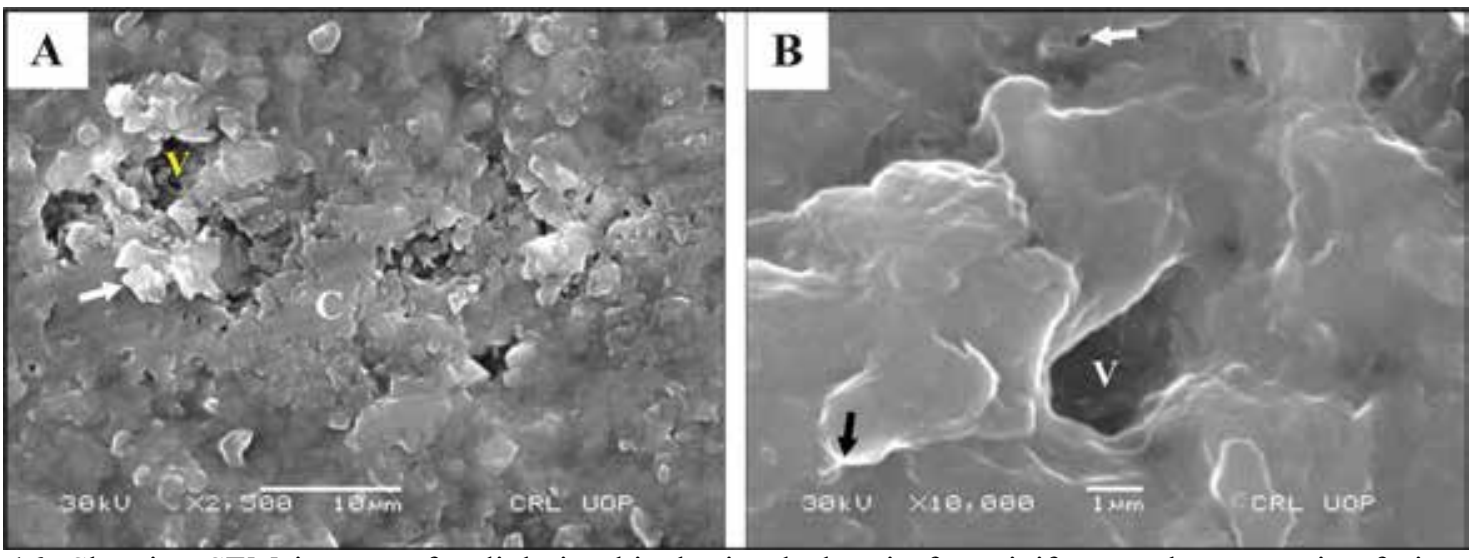

Fig 16. Showing SEM images of radiolarian bioclastic planktonic foraminifera wackestone microfacies. (A) Showing vugs (V), cementation (C) and quartz (white arrow). (B) Showing vugs (V), zoning of quartz (black arrow) and pores (white arrow).

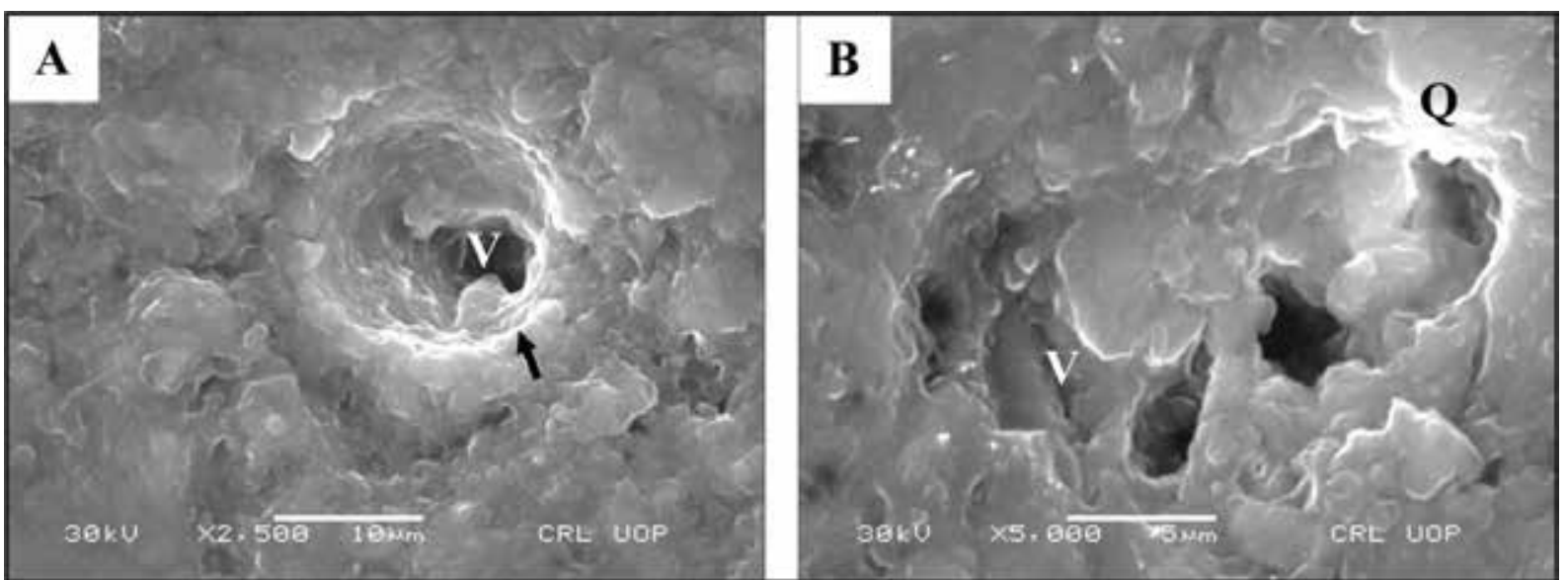

Fig 17. Showing SEM images of radiolarian bioclastic planktonic foraminifera wackestone microfacies. (A) Showing vuggy porosity (V) and zoning of quartz in vuggy porosity (black arrow). (B) Showing vuggy porosity $(\mathrm{V})$, quartz (Q).

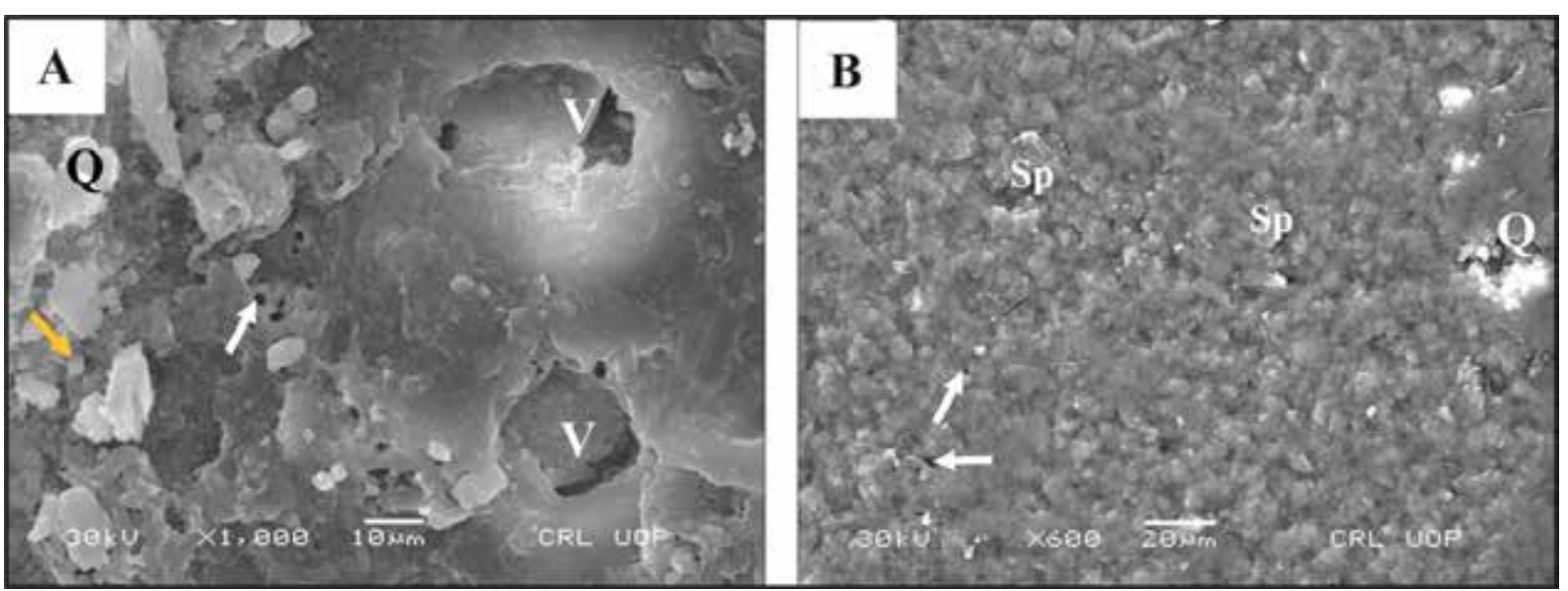

Fig 18. Showing SEM images of dolomitic mudstone sub-microfacies. (A) Showing quartz (Q), dolomite grains (yellow arrows), pores (white arrow) and vuggy porosity (V). (B) Showing shelter pores (Sp), quartz (Q), pores (white arrows). 


\section{CONCLUSIONS}

The present research study deals with reservoir characterization of Upper Cretaceous Kawagarh Formation, Qamar Mela Section, Nizampur Basin. The following conclusions have been extracted from the study.

1. The Upper Cretaceous Kawagarh Formation exposed in Qamar Mela Section, Nizampur Basin is predominantly comprised of very thin to thickly bedded limestone and marl.

2. The field features of Kawagarh Formation include weathering, fracturing, and veins. The lower contact of Kawagarh Formation is conformable with Lumshiwal Formation of Middle Cretaceous age while upper contact is disconformable with Lockhart Formation of Paleocene age.

3. The diagenetic fabrics in Kawagarh Formation are compaction, dissolution, pyrite precipitation, development of types of cement (acicular and Syntaxial overgrowth), dolomitization and fractures representing shallow marine, meteoric and burial diagenetic environments.

4. The dissolution, fracture and dolomitization enhances the reservoir potential while cementation, compaction and pyrite precipitation reduces reservoir potential of Kawagarh Formation.

5. Plug porosity and permeability shows that the Kawagarh Formation is having very low porosity permeability i.e. porosity $1.69 \%$ and permeability $0.267 \mathrm{Ka} / \mathrm{md}$.

6. SEM analysis showed different type of

7. porosity that includes vuggy, shelter and intergranular which enhanced the reservoir characterization.

\section{REFERENCE}

Ahsan, N., 2008. Facies Modeling, Depositional and Diagenetic Environments of Kawagarh formation, Hazara Basin, Pakistan. Unpublished Ph.D. thesis. Punjab University, Lahore, Pakistan.
Ahsan, N., Iqbal, M. A. and Chaudhry, M.N., 1994. Deposition and Diagenesis of Kawagarh Formation, Changla Gali, Murree-Ayubia Road, Hazara, Pakistan. Pak. J. Geol., V. 2 \& 3 No.1,. 41-52

Ahsan, N., and Chaudhry, M.N., 1998, Facies and Microfacies analysis of Kawagarh Formation of Hazara Basin, Pakistan. 13th Himalaya-Karakoram-Tibet Workshop, Abstract Vol. 31, Geol. Bull. University of Peshawar.

Ahsan, N., Chaudhry, M.N., Sameeni, S.J. and Ghazanfar, M., 1993. Reconnaissance microfacies studies of Kawagarh Formation Jabri area, Hazara. Pak. Jour. Geol., 1 No.2, 32-49

Ahsan, N., Chaudhry, M.N., Ghazanfar, M. and Sameeni, S.J., 1993b. Microfacies analysis of Kawagarh Formation of Borian Area, Southern Hazara. Geol. Bull. P.U., V. 28.

Bathrust, R. G. C., 1975. Carbonate Sediments and Their Diagenesis, pp. 658. Elsevier, Amsterdam.

Boggs, S., 1995. Principles of Sedimentology and Stratigraphy, 774pp. Prentice Hall, Englewood Cliffs, NJ.

Burbank, D. W., 1982. The Chronologic and Stratigraphic Development of the Kashmir and Peshawar Intermountain basins, North-western Himalayas: Unpublished Ph.D. thesis, Dartmouth college, USA.

Butt, A.A., (1986): Plate Tectonics and Upper Cretaceous biostratigraphic synthesis of Pakistan. Acta Mineralogica Pakistanica 2: 60-64.

Chaudhry, M.N., Ghazanfar, M., Ahsan, N., 1994b. Rates of Sedimentation of Kawagarh Formation at Giah and Timing of Uplift at K-T boundary. Pakistan Jour. Geol., V. 2 \& 3, No.1, 29-32

Chaudhry, M.N., M. Ghazanfar, N. Ahsan, 1994b. Rates of Sedimentation of Kawagarh Formation at Giah and Timing of Uplift at K-T boundary. Pak. Jour. 
Geol., . 2 \& 3, No.1,29-32

Chaudhry, M.N., Mahmood, T. Ahmed, R. and Ghazanfar M., 1992a. A Reconnaissance Microfacies Study of Kawagarh Formation Near Giah, Abbottabad-Nathagali Road, Hazara, Pakistan. Jour. Hyd. Res. 4/2, 1932

Cotter, G. De P., 1933. The Geology of the Part of the Attock District, West of Longitude 7245 E: India Geol. Surv., Mem., V.55, P. 61-63.

Fatmi, A.N. (1973):Lithstratigraphic units of Kohat-Potowar Province, Indus basin, Mem. Geol. Surv. Pakistan, 10: 1-80

Fatmi, A. N., 1977."Mesozoic" in Shah, S.M.1 Ed.) Stratigraphy of Pakistan, GSP, Memoirs.

Flügel, E., 1982. Microfacies Analysis of Limestones, pp. 633. Springer-Verlag, Berlin.

Flügel, E., 2004. Microfacies of Carbonate Rocks: Analysis, Interpretation and Application, Springer-Verlag, Berlin Heidelberg 2004.

Garzanti, E. 1992. Stratigraphy of the Early Cretaceous Giumal Group Zanskar Range, Northern India. Riv. It. Paleont. Strat., 97, 3-4.

Ghauri, A. A. K., Pervez, M. K.. Riaz, M., Rehman, O. U., Ahmad, I. and Ahmad, S., 1991. The Structure and Tectonic setting of Attock-Cherat and Kalachitta ranges in Nizampur area, N. W. F. P. Pakistan Kashmir Journal of Geology, Vol.8 and 9, p.

Ghazanfar, M. 1993. Petrotectonic Elements and Tectonic Framework of Northewest Himalaya. Ph.D thesis, University of the Punjab, 1 \& 2, . 1-380.

Kazmi, A.H. and Jan, M.Q., 1997, Geology and Tectonics of Pakistan. Graphic Publishers, Karachi, 54

Kazmi, A.H. and M.Q. Jan, 1997. Geology and Tectonics of Pakistan. Graphic publishers Pakistan.
Kazmi, A. H and Abbasi, I. A., 2008. Stratigraphy and Historical Geology of Pakistan. (Published by: National Center of Excellence in Geology, University of Peshaer).

Latif, M.A. 1970b. Micropalaeontology of the Chanali Limestone, Upper Cretaceous of Hazara West Pakistan. Jb. Geol. B.A. Sonderband, 15, 25-61

Le Fort, P., 1975. Himalayas: The collided range. Present Knowledge of the continental arc. Am. Jour. Sci. 275A, 1-45.

Meissner, C. R., Master, J. M., Rashid, M. A. and Hussain, M., 1974. Stratigraphy oh the Kohat Quardangle, Pakistan.

Middlemiss, C. S., 1896. The geology of Hazara and Black Mountains. India. Geol. Surv., Mem., 26, 1-302

Norton, I.O. and J.G. Sclater, 1979. A model for the evolution of the Indian Ocean and the breakup of Gondwanaland: Journal of Geophysical Research, 84, 6803-6830.

Powell, C. McA., 1979. A speculative tectonic history of Pakistan and surroundings: Some constraints from the Indian Ocean. In: Farah, A. \& DeJong, K.A. eds. Geodynamics of Pakistan. Geol. Surv. Pak., Quetta.

Reading, H.G. 1996. Sedimentary Environments: Processes, Facies and Stratigraphy. Blackwell Scientific Publications. 688

Schmoker,J. W. and Halley, R. B, 1982. Carbonate porosity versus depthapredictablerelation for south Florida. Bull. Am. Ass. Petro. Geol. 66, 2561-2570.

Shah, S.M.I., 1977, Stratigraphy of Pakistan: Geol. Surv. Pakistan, Quetta, Mem. Geol. Surv. 12,138

Sokolove, B.A. and Shah, S.H.A, 1966. Major tectonic features of Pakistan, Part-I, Western Provience. Jour. Sci. Ind. Res., 4,175-199

Tahirkheli, R.A.K., 1970. The geology of Attock-Cherat Range, west Pakistan. 
Geol. Bull. Univ. Peshawar 5, 1-26.

Tucker, M.E. 1988. Techniques in Sedimentology, Blackwells, Oxford. 394.

Tucker, M. E. and Wright, V. P., 1990. "Carbonate Sedimentology", Blackwell Scientific Publication, Oxford, London, UK.

Wadia, D.N., 1931. The syntaxis of the Northwest Himalaya, its rocks, tectonics, and orogeny. India Geol. Surv. Recs., 65/2,189220. 